in close translation; commentary linking, explaining, or amplifying the above texts, whenever necessary or desirable; reflections on and assessments of the documents from the perspective of the mature narrator; finally, a frame outlining the purpose, procedure, and goal of the exploration to be undertaken and inviting readers to make their own assessment of the narrator, then and now.

This approach, I believe, enables readers to extricate from the memoir the degree of information and truthfulness they expect or are interested in, be it factual, psychological, emotional, or aesthetic, without having to question or try to trace the presenter's perspective and motive. And just as it is up to the viewer of a painting to read meaning into or out of it and up to listeners to establish a relation with the music they hear, so the reader of such a memoir need not worry about its historical accuracy but can accept it as a glimpse into the life of another being, hopefully presented with such aesthetic components as form, structure, and style but without hiding manipulation or invention.

Elizabeth Welt Trahan Amherst College (retired)

\section{Leadership for a Diverse Profession}

\section{To THE EDITOR:}

Marjorie Perloff offers a most interesting and thoughtful survey of the state of the profession in her 2006 Presidential Address (122 [2007]: 652-62), but I must point out one blind spot, unfortunately common for people with prestigious appointments in English and foreign language departments. She writes, "Given these aporias of literary study, administrators are beginning to argue, perhaps English departments should concentrate on the study of composition and rhetoric, disciplines that really do teach students things they need to know, and the foreign literature departments should focus on language learning, so important in business, professional life, and especially government service" (656). She implies this is a future possibility we should watch out for rather than a present reality. This passage suggests the former president of the MLA was, unfortunately, oblivious to the actual state of the profession. Overwhelmingly, English departments are composition departments, and foreign language departments are "language learning" departments. A glance at the course offerings of almost any college or university shows that literature courses make up only a fraction of the departments' total teaching load. The higher one's professional status, of course, the less likely one is to teach the nonliterature courses, leaving that work to graduate students, part-timers, temps, composition and language education specialists, and a significant percentage of the faculty at most nonelite schools (for whom such courses constitute a chunk of their teaching load) - that is, to the bulk of the profession below the top tier.

Look, I'm not saying that the MLA should reorient itself to focus on the predominant mode of work that English and language departments actually do-the literary focus is extremely valuable, the lure that got most of us into this business in the first place. I'm asking for a leadership that can see below the summit.

What would happen if the MLA elected its presidents from an activist bottom rather than a prestigious top?

James $D$. Sullivan

Illinois Central College

\section{Reply:}

I am grateful to James D. Sullivan for raising this issue. He is right to remind us that, even now-not just in some hypothetical future-in most large state universities, "English departments are composition departments, and foreign language departments are 'language learning' departments." The truth, I suppose, is that, whatever the reality on the ground, the discourse of our discipline-indeed, of any academic discipline-draws its inferences from graduate programs at the top universities, and at these universities, as well as at liberal arts 
colleges, a whole array of "literature" and "cultural studies" courses continue to be taught and to generate faculty positions. But the model in question is, as Sullivan complains, a top-down one, and I agree that it is time to pay attention to the "activist bottom." Indeed, Sullivan will be happy to hear that Gerald Graff, the 2008 MLA president, whose fields of specialization include composition theory and the pedagogy of English teaching, plans to focus on precisely the issues Sullivan has in mind.

Marjorie Perloff Stanford University

\section{The University and Class Warfare}

\section{To THE EDITOR:}

I was pleased to see Stephen Schryer's contribution, in "Fantasies of the New Class: The New Criticism, Harvard Sociology, and the Idea of the University" (122 [2007]: 663-78), to a revival of interest in postwar American sociological scholarship, and I found his comparison between that scholarship and the New Criticism convincing. I was particularly pleased by his consideration of Alvin Gouldner's The Future of Intellectuals and the Rise of the New Class, a work of critical theory whose important implications for humanistic study have never received sufficient attention. My only qualification is to ask whether Schryer might have been too quick to present the book as typical of Parsonian, "Harvard" sociology. Gouldner was among the New Left sociologists who rebelled against that school, and his position was distinctive as an audacious alternative both to it and to leftist critiques of it.

Schryer is correct in pointing to Gouldner's glaring "failed prophec[y]"-his 1979 interpretation of Ronald Reagan's failure to win the 1976 Republican presidential nomination as a sign of the replacement of the old ruling class of "the moneyed bourgeoisie" by the "new social order of professionals, centered in the university, that would extend and perfect the United States welfare state" (663). As Schryer sadly notes, with Reagan's reemergence in 1980, the old class "found a powerful voice within the New Right and the rejuvenated Republican party, which gutted what was left of the welfare state and launched an all-out attack on the educated liberal morality of the intellectuals" (664). This attack has continued unabated through recent jihads like David Horowitz's Academic Bill of Rights and Republicans' ridicule of John Kerry's French looks or Al Gore's scholarly demeanor. Whether or not the attack has shot its wad and will recede before a renewal of liberal politics and public policy is a key question of the present moment.

My sense is that the "new social order of professionals ... that would extend and protect the United States welfare state," extolled by social scientists in the 1950s and 1960s, may have had it right, at least more than was granted by those who savaged them from both the right and left (even though the social scientists' agenda contained a large dose of selfpromotion). From today's vantage point, much more, not less, implementation of the welfare state, especially in programs like the War on Poverty, would undeniably have been a preferable alternative.

As for Gouldner, perhaps his failed prophecy can be partly redeemed by viewing it as an inadvertent confirmation of his case that humanistic New Class intellectuals, "while morally ambiguous, may still be the best card history has dealt"-especially for the political left, which has been pummeled by reactionism from Reagan to George W. Bush. In a chapter titled "The New Class as a Speech Community," Gouldner develops the notion of "the culture of critical discourse" (CCD), his acknowledged variation on the sociolinguist Basil Bernstein's "elaborated code," as the defining trait of humanistic intellectuals (as opposed to the technocratic ones, who are a rival branch of the New Class). Gouldner was among the many modern leftists who reluctantly lost hope in the revolutionary possibilities of the working class, for reasons including Bernstein's accounts of the cognitive and discursive restrictions contempo- 